occupations as mere idleness. Long rambles, such as were the delight of my boyhood, when we used to go miles in search of a wasp's nest, are in certain modern schools abolished by compulsory games. Some day or other (the reform will not come in my time) we shall recognise that the chief occupation of the young child should be spontaneous natural play.

That interesting book called "Public Education," now nearly a hundred years old, in which we find a description of the methods practised by Rowland Hill and his brothers at Hazelwood and Bruce Castle, is inspired by the desire to make education natural and not merely artificial; so is that older and still better book, "Edgeworth on Practical Education." There are modern English schools which give fair opportunity for natural education. I pass over some, perhaps many, out of mere ignorance; but I will name two which I happen to know-Bedales. School and the Friends' School at Bootham, York, both of which have discovered how to combine natural education with efficiency.

\section{Heuristic Methods.}

Dr. Armstrong's heuristic method is well known in this section. He tells us that neither the name nor the thing is altogether new, and the same may be said of nearly every educational expedient. Promising schemes are proposed, tried perhaps on a small scale, and dropped, often for lack of enterprise on the part of the teachers, and years after someone discovers them again. Dr. Armstrong tells us ${ }^{1}$ where he got the name, and quotes a passage from Edmund Burke, which clearly describes the method. It is now a good many years since I saw Mr. Heller give several lessons on this plan in elementary schools in London, and was then permanently convinced of the real value of the heuristic method. I only wish that we had a score of such, each worked out as carefully as Dr. Armstrong's model.

The method need not be confined to experimental science, nor to science at all. I have attempted something of the same kind in elementary biology. Why should not teachers of history carry out a little historical research with the help of an upper form? Suppose that the subject chosen was English town and country life in the sixteenth century. Harrison's Description of England, Shakespeare's plays, Walton's Lives, some of the modern books which collect the testimony of foreign visitors during the reigns of Elizabeth and James I., Spenser's View of the State of Ireland, and Hume Brown's Scotland before I70o are, let us suppose, accessible to the class. Useful materials from these and any other sources might be arranged in a cardindex. Cooperation is eminently desirable, and a little club of pupils might well make their index in common. Then the materials should be treated in literary form, every detail of literary workmanship receiving attention. I fully expect to be told that this plan has actually been tried in some school or other. The historical researches of the school may give opportunity for the use of foreign languages, for map-drawing, or for the handling of statistical information.

Mr. Greening Lamborn's "School History of Berkshire ${ }_{2}$ is interesting as an investigation carried out by and for the boys of an Oxford school. It will be read in a very different spirit from that with which the condensed school-history of England is received, and will no doubt suggest more work of the same kind. The share of the bovs may well grow larger and larger.

The advocates of learning by inquiry and learning by doing will descend even into the nursery. What an opportunity is afforded by tors!-an opportunity that those who purchase all their children's toys throw awav. Surely every little girl ought to be encouraged to make plausible dolls out of the rag-bag, every little boy to make his own menagerie, his own boats and whistles and sledges. Even the bought toy gives opportunity for inquiry. Ask anv child if he has noticed that the animals of the Noah's Ark are always thicker at one end. usually the hinder end. There is a reason for this. and a curious reason, which the child may be helped to discover. 1 "The Teaching of Scien:ific Method, \&c.," r903, p. 235.
2 Clarendon Press, I 08.

No. 2032, VOL. 79$]$

\section{Mastery of Something}

Let us indulge less than we do the passion of intellectual avarice, if only because avarice blinds us to the relative values of things. The old French anatomist, Méry, said of himself and his colleagues that they were like the ragpickers of Paris, who knew every street and alley, but had no notion of what went on in the houses. The accumulation of miscellaneous knowledge of useful things, copious, inexact, inapplicable, may, like rag-picking, leave us ignorant of the world in which we live. Let us try to reach the inner life of something, great or small. The truly useful knowledge is mastery. Mastery does not come by listening while somebody explains; it is the reward of effort. Effort, again, is inspired by interest and sense of duty. Interest alone may tire too quickly; sense of duty alone may grow formal and unintelligent. Mastery comes by attending long to a particular thing-by inquiring, by looking hard at things, by handling and doing, by contriving and trying, by forming good habits of work, and especially the habit of distinguishing between the things that signify and those that do not.

It is too much to expect that mastery will often be attained in school. School is but a preparation, not I think for promiscuous learning, but for the business of life. The school will have done its part if in favourable cases it has set a pattern which will afterwards develop itself naturally and harmoniously.

\section{CHEMISTRY AT THE BRITISH} ASSOCIATION.

$A \mathrm{~N}$ unusually large number of chemists attended the meeting, and in consequence very many papers, some of considerable importance, were read before the section. Chief interest attached to the discussions, which were well supported and of real value; it is worthy of consideration whether it be not advisable to devote the programme almost entirely to thęse. On no other occasion is it possible to have what may be termed "borderland problems" discussed conjointly with representatives of other sciences.

The most novel contribution to the section was that made on behalf of Dr. Mond, describing the preparation and properties of cobalt carbonyl. The preparation of this substance has hitherto been attempted in vain, though the remarkable compounds of carbon monoxide with nickel or iron have been known since $\mathrm{r} 890$. It is now obtained by acting on finely divided cobalt with carbon monoxide at 100 atmospheres pressure between $150^{\circ}$ and $200^{\circ}$. It forms large orange crystals, which decompose in the air, yielding a deep violet substance.

Sir William Ramsay related in popular terms the wellknown story of the discovery of argon, helium and other gases in the atmosphere. Following him, Prof. Hartley described his researches on the detection of lithium in radio-active minerals, which are of importance in connection with the assumed transmutation of copper contained in solution into lithium, neon and possibly other substances. He adduced much experimental work to show that it is impossible to corroborate Sir William Ramsay's statements that potassium is a more widely distributed element than lithium, or that lithium is an unlikely constituent of dust, glass, copper, \&.c.

Prof. Rutherford described experimental work showing that the amount of neon in $1 / 15$ c.c. of air readily gives the neon spectrum, and can so be detected. He attributed Sir William Ramsay's assumed formation of neon by the action of the emanations on water to a slight leakage of air during the experiment, and claimed that when air is air dir William Ramsay, replying, upheld his experiments, but agreed that the formation of lithium from copper was of a less degree of certainty than the other transmutations he has observed.

Sir James Dewar communicated a paper from Dr. Kamerlingh Onnes describing the apparatus used to liquefy helium. From the study of the isothermals of helium the critical temperature was found to lie between $5^{\circ}$ and $6^{\circ}$ absolute, indicating that the gas must be cooled below $30^{\circ}$ absolute before it will cool on expansion. By boiling 
hydrogen under reduced pressure $15^{\circ}$ absolute were obtained, and using 200 litres of helium it was possible to continue the experiment long enough to obtain liquid helium boiling at $4^{\circ} \cdot 5$ absolute. A temperature of $3^{\circ}$ was reached without any sign of solidification. Dr. Onnes hopes to reach $I^{\circ} \cdot 5$ absolute. Sir James Dewar pointed out the intimate connection between low-temperature research and the theory of van der Waals, and gave an account of anticipations of and experiments on the liquefaction of helium, showing how statements made in his presidential address at Belfast in 1902 had proved to be accurate.

A discussion on the nature of chemical change was opened by Prof. H. E. Armstrong, who contended that dissolution involves associative and distributive changes. Water is supposed to be a complex mixture of active and inactive molecules, the active molecules being hydrone $\left(\mathrm{OH}_{2}\right)$ or hydrone-hydrol $\left(\mathrm{H}_{2} \mathrm{O}<\mathrm{OH}\right)$, and the inactive molecules closed systems formed by the association of two or more simple molecules. In a solution of hydrogen chloride molecules of the type $\mathrm{H}_{2} \mathrm{O}<_{\mathrm{Cl}}^{\mathrm{H}}$ and $\mathrm{HCl}<_{\mathrm{H}}^{\mathrm{H}}$ exist, the latter being the more prevalent in weaker solutions. The properties of aqueous solutions were explained on this hypothesis. Sir Oliver Lodge pointed out that these hydrogen chloride molecules were not very different from the hydrated ions postulated by followers of the ionic theory. Subsequently Prof. Armstrong's theory was adversely criticised by Dr. Findlay, Dr. Donnan, and Dr. Wilsmore.

The discussion on problems of fermentation was arranged to focus as clearly as possible the present state of knowledge. Dr. Harden gave an account of the present position of the zymase theory. He showed that the fermentative activity of yeast juice is due to two substances, which may be separated by passing through a Martin dialyser at 50 atmospheres pressure. The residue contains the enzyme, the filtrate the so-called co-enzyme, and these only ferment sugar when united, either separately being inactive. Sodium phosphate causes an increase in the rate of fermentation; apparently a hexose phosphate is first formed, which breaks down to fermentable sugar and sodium phosphate. Prof. Adrian Brown discussed cellular fermentation, which is generally stated to be controlled by the rate of diffusion of the sugar fermented into the cell. Under normal conditions the enzymes are inside the cell and do not leave it, but under unhealthy conditions the enzyme probably leaves the yeast cell.

Dr. A. Slator pointed out that the conversion of glucose into alcohol and carbon dioxide is a series of reactions, and that the velocity of change is determined by the rate of the slowest reaction. The rate of fermentation is proportional to the amount of yeast present, and independent of the concentration of the sugar. He suggested that glucose and fructose are fermented by one enzyme, mannose by another, and galactose by a third. Galactose is fermented only by yeasts which have been grown in the presence of galactose.

Dr. E. F. Armstrong dealt with the role of enzymes in fermentation. The mechanism is quite distinct from the sucroclastic enzymes; in the case of glucose, fructose, or mannose the first step is the conversion, by means of an enzyme, into the common enolic form, and the formation of a compound between enzyme and enolic form. He further alluded to the question of adaptation of the organism to nutrition, pronouncing in favour of the view that something which is already present, though hitherto latent, is developed in response to stimulation, and opposed the idea that an altogether new enzyme is formed. This view was developed by Prof. Gotch and Prof. Keeble. Prof. H. E. Armstrong described the recent work of F. Ehrlich, who has shown that the supposed by-products of alcoholic fermentation are in reality produced by the action of yeast on amino-acids derived from the protein complex.

Messrs. Julian L. Baker and H. F. E. Hulton contributed a preliminary note on the action of the enzymes NO. 2032 , VOL. 78 ] of malt on ungerminated cereals. A considerable increase in the diastatic activity of barley takes place when it is digested in presence of malt extract.

Prof. W. H. Perkin gave a brief account of the history of synthetical progress in the terpene series, and. described the methods and stages in the process of synthesis of terpineol, carvestrene, and also the first optically active terpineol. Subsequently, Dr. Weizmann dealt with the methods suggested for the preparation of synthetical camphor on a commercial scale. Under laboratory conditions many of the processes yield from 70 per cent. to 80 per cent. of the theory, but on a large scale the yield and purity of the product have frequently left much to be desired. A method was described of converting pinene hydrochloride into isobornyl acetate by means of glacial acetic acid and zinc chloride.

Dr. T. M. Lowry gave an account of the work done by the committee on dynamic isomerism. The most important feature of the year's work has been the discovery of a group of agents by means of which isomeric change-in the case of camphor derivatives---can be retarded or completely arrested. Such are carbonyl chloride and acety] chloride; the action of the former probably depends on its power of converting ammonia and bases, such as piperidine, into neutral carbamides. The relationship between absorption spectra and isomeric change has been tested in the case of a number of optically active camphor derivatives.

A further case of dynamic isomerism observed in derivatives of oxymethylene camphor was described by Prof. W. J. Pope and Mr. John Read.

Dr. J. A. Smythe dealt with problems of tautomeric change in a paper on the reaction between benzyl sulphoxide and hydrochloric acid.

Matter of very great interest was contained in a paper by Prof. Adrian Brown on the selective permeability of certain seeds. The coverings of grains act as semipermeable membranes towards sulphuric acid solutions; water passes into the grain, and the acid solution becomes more concentrated. The membrane prevents the passage even of 36 per cent. acid, but in this case water passes out of the grain to dilute the acid. The membrane is likewise impermeable to most salts. Iodine, however, does pass through, also mercuric chloride and cyanide, but no other mercury salts. Organic acids, such as acetic acid, pass through the membrane, but not lactic acid. The grains thus exercise selective permeability, the permeable compounds being non-dissociated or only very slightly dissociated.

A report on colloidal chemistry was presented by Prof. Procter, and approved for printing in extenso. This deals very fully with the properties of colloids and with the history of the more recent development of the subject, the industrial importance of which is being gradually recognised. Not only are tanning and dyeing particularly concerned with the mutual precipitation of colloids, but such industries as rubber, gums, dextrin, glue, and cellulose are all colloidal, as also many inorganic industries, e.g. glass manufacture and pigment making. Such a summary is very opportune at the present moment.

Dr. A. Findlay gave a preliminary account of an investigation of the influence of colloids on the absorption of gases by water, a subject which has a bearing on the absorption of carbon dioxide by blood. Most of the colloids studied had relatively little influence on the solubility of carbon dioxide in water.

Prof. Pope and $\mathrm{Mr}$. Wm. Barlow gave a short account of their theory of valency as applied to elucidating the structure of the open-chain hydrocarbons. This was illustrated by some excellent models. The subject of valency was further dealt with from a theoretical point of view by $\mathrm{Mr}$. H. Bateman, who defines valency as a number which indicates the degrees of freedom for departure from the existing state of motion of the charged particles which constitute the element.

Dr. J. Timmermans showed an apparatus and described investigations on the densities of liquids from $0^{\circ} \mathrm{C}$. to their melting points in continuation of Young's experiments on the rectilinear diameter.

Dr. H. J. S. Sand gave a demonstration on the rapid 
electro-analytical separation of metals with the apparatus described in the Journal of the Chemical Society. A somewhat similar apparatus was briefly described by Dr. F. M. Perkin.

Interesting results obtained with transparent silver and other thir metallic films were shown by Prof. T. Turner. Thin gold leaf becomes transparent when heated to about $550^{\circ}$; the change does not depend on the nature of the atmosphere. Thin silver leaf requires the presence of air or oxygen for a similar change. Thin sheet copper, heated to $200^{\circ}$, becomes transparent, and transmits yellow-green light quite freely.

A discussion on the practical utilisation of peat was opened by a paper from Dr. Woltereck, dealing with the production of ammonia from atmospheric nitrogen by means of peat. Experiments have shown that a mixture of nitrogen and hydrogen passed over reduced iron at a low heat produces ammonia, and that the presence of oxygen and water was of importance. Finally, the hydrogen was omitted and peat substituted for the iron with satisfactory results. It is claimed that atmospheric nitrogen cooperates in the formation of ammonia. Subsequent speakers included Prof. Ryan, Prof. Turner, Sir James Dewar, and Mr. K. B. Eller, but the discussion failed to bring out any new facts of importance.

The aromatic nitroamine committee (secretary, Dr. K. J. P. Orton) reported on the transformation of nitroamino-benzenes into nitro-anilines. The influence of the solvent, nature of the acid catalyst, and the effect of concentration of the acid and temperature have been studied.

The report of the committee for the study of hydroaromatic substances (secretary, Prof. A. W. Crossley) contained the usual valuable summary of recent work in this field, together with new investigations on dimethyldihydrobenzene.

\section{GEOLOGY AT THE BRITISH ASSOCIATION.}

THE geologists who were privileged to attend the meetings of Section $\mathrm{C}$ at Dublin will always recall with pleasure the kindly welcome and helpful assistance extended to them by the home geologists. Not only did they give us a president whose brilliant address promises to be historic, and arrange for our benefit a delightful series of excursions in the neighbourhood of Dublin, but they communicated many papers of great interest, and took a very active part in the work of the section.

Prof. Cole's lecture on the geology of the country round Dublin, which followed the president's address, summarised the principal points of interest in the district, and led us to a clearer view of the many important features we were enabled to see in the afternoon excursions organised and led by Mr. H. J. Seymour and others.

Prof. Cole also contributed two other papers, one dealing with the examination of the stones brought up during the dredging expeditions of the Fisheries Branch of the Department of Agriculture and Technical Instruction for Ireland. The discovery, off the coast of Kerry, of abundant flints chalk, glauconitic chalk, and Milioline limestone showed that the Cretaceous and Eocene seas extended to an unknown distance towards the west.

The other paper was explanatory of an exhibit of the types of rock formed during the intervals between the basaltic eruptions in the north of Ireland in Eocene times. It was urged that the red lateritic zone represents basalt altered in situ, and is clearly connected with the climatic conditions of Eocene times. The pale bauxites are considered to be derived from sporadic eruptions of rhyolite, and a thin bauxite layer overlying the pisolitic iron-ore may in part be formed by wind-borne material.

Messrs. R. J. Ussher, H. J. Seymour, E. T. Newton, and R. F. Scharff gave the results of their joint work in the exploration of the Cave of Castlepook, near Doneraile. Both the geological evidence and the characteristics of the fauna collected lead towards the conclusion that the cave is pre-Glacial in age, and support the opinion that
Ireland has not been joined to England by land in Glacial or post-Glacial times.

Messrs. H. B. Muff and R. Carruthers described the structure of the Leenane district, co. Galway, and Prof. S. H. Reynolds and Mr. C. I. Gardiner dealt with rocks along the same strike in the Tourmakeady district, co. Mayo.

The veteran geologist Mr. G. H. Kinahan, although prevented from attending the meeting through illness, sent a paper on the raised beaches of the Liffey Valley, and $\mathrm{Mr}$. H. Bolton reported the details of a boring in the Lower Coal-measures at the Emerald Pit, Dungannon.

The igneous rocks of the seldom visited outer Blasket Islands were described by the president.

Besides the above papers dealing with Irish geology, a fine collection of photographs of geological interest, and a typical set of Irish rocks, were exhibited by $\mathrm{Mr}$. R. Welch and other local workers.

Desert phenomena, which have played so important a part in the proceedings of the section for some years past, were again discussed in several important papers. Dr. W. F. Hume contributed notes on the petrography of Egypt, Mr. G. W. Grabham dealt with the well-water supply of the north-east Sudan, Dr. A. Hutchinson gave the results of a chemical and physical examination of some remarkable crystals of dolomite obtained from Algeria, while fossil deserts were referred to in the report of the Trias Committee. With the view of obtaining further data regarding the conditions under which the Triassic rocks of Britain were laid down, a new research committee was appointed to conduct investigations in the marginal parts of the Sahara about Biskra, in Algeria, and Mr. J. Lomas will shortly proceed to Africa to make observations bearing on the point.

In glacial geology two papers were presented. Dr. Dwerryhouse, in reading the report of the Erratic Blocks Committee, showed that there is still much useful work to be done, despite the long time the committee has been at work. Prof. W. M. Davis, of Harvard University, in dealing with the glacial erosion in north Wales, confined his remarks to the Snowdonian district. He demonstrated that in Tertiary time the mountains existed as a group of monadnocks surmounting a peneplain which extended far into mid-Wales. During the Glacial epoch the intervening valleys were deepened, and cwms were formed which showed that glacial erosion in certain valleys amounted to 400,600 , or 800 feet.

In mineralogy and petrography eight important papers were read. The president, in the course of an examination of the Deccan basalt, found them to contain native iron and gold. Dr. A. Hutchinson described a new method of drawing stereographic projections of crystals, and exhibited a protractor designed for the use of students of crystallography. Dr. H. A. Bemrose showed and described a number of slides illustrating the microstructure of Derbyshire limestones, and $\mathrm{Mr}$. H. Brodrick contributed a note on the structure and occurrence of cave pearls. Dr. Tempest Anderson's paper on the changes in the Soufrière of St. Vincent was a continuation of the work done by Dr. Flett and himself on the remarkable volcanic eruptions which occurred in the West Indies a few years ago.

Dr. J. Milne, in discoursing on the duration and direction of large earthquakes, showed that while small earthquakes have a duration of a few seconds near their origin, and at a distance of fifty to 100 miles they may not be recordable, large earthquakes suffer no appreciable decay during transmission, and their duration appears to increase rather than decrease. Another observation in connection with recent seismological observations is that large earthquakes travel farthest in particular directions.

Other papers on earth movements were contributed by Prof. W. H. Hobbs and Dr. Woolacott. The former dealt with the recent earth movements within the basin of the Laurentian lakes, and by methods of precise levelling he was able to demonstrate that the recent tilting of the province proceeded at variable rates at different points.

Dr. Woolacott. in describing a case of thrust and crush No. 2032 , VOL. 78] 